Penelitian

\title{
Performa dan Karakteristik Semen serta Freezability Spermatozoa Ayam IPB-D1 dengan Konsentrasi Immunoglobulin Yolk Berbeda
}

\section{Performance, Semen Characteristics and Sperm Freezability of IPB-D1 Chicken with Different Immunoglobulin Yolk Concentrations}

\author{
Yusman Setiawan', Niken Ulupi ${ }^{*}$, Cece Sumantri', Raden lis Arifiantini' \\ 1'Departemen Ilmu Produksi dan Teknologi Peternakan, Fakultas Peternakan, \\ Institut Pertanian Bogor, Jawa Barat \\ ${ }^{2}$ Departemen Klinik, Reproduksi dan Patologi, Fakultas Kedokteran Hewan \\ Institut Pertanian Bogor, Jawa Barat \\ *Penulis untuk korespondensi: niken.ulupi@gmail.com \\ Diterima 4 Agustus 2020, Disetujui 29 November 2020
}

\begin{abstract}
ABSTRAK
Ayam IPB-D1 merupakan jenis ayam lokal dari hasil persilangan antara jantan $F_{1}$ PS (Pelung x Sentul) dengan betina $F_{1}$ (Kampung $x$ Ras pedaging paren stock Cobb). Penelitian ini bertujuan untuk mengevaluasi performa, kualitas semen, dan freezability spermatozoa ayam IPB-D1 pada konsentrasi Immunoglobulin Yolk (IgY) berbeda. Materi yang digunakan yaitu ayam IPB-D1 jantan sebanyak 20 ekor, terdiri atas 10 ekor ayam dengan konsentrasi IgY rendah dan 10 ekor IgY tinggi dengan ayam umur 8 bulan. Variabel yang diamati yaitu performa yakni konsumsi pakan, pertambahan berat badan, morbiditas dan mortalitas, kualitas semen segar dan kualitas semen beku (freezability). Data dianalis menggunakan uji-t menggunakan program SAS dengan membandingkan antara konsentrasi IgY tinggi dan IgY rendah. Hasil analisis performa ayam IPB-D1 tidak berbeda ( $P>0.05)$ terhadap IgY yang berbeda. Hasil kualitas semen menunjukkan perbedaan yang signifikan terhadap konsistensi semen dan motilitas, viabilitas, konsentrasi serta konsentrasi spermatozoa per ejakulat. Ayam IPB D-1 pada dua konsentrasi IgY tidak berbeda nyata (P>0.05) terhadap motilitas semen segar dan recovary rate, namun Ayam IPB D-1 dengan konsentrasi IgY tinggi memiliki motilitas spermatozoa pasca thawing lebih baik daripada $(\mathrm{P}<0.05)$ Ayam dengan konsentrasi IgY yang rendah.
\end{abstract}

Kata kunci: ayam IPB-D1, freezability spermatozoa, karakteristik semen, performa

\begin{abstract}
IPB-D1 is a local type of chicken crossbreed of F1 Pelung $x$ Sentul rooster with F1 Kampung $\mathrm{x}$ broiler parent stock Cobb hen. This study aimed to evaluate the performance of rooster, its semen quality, and the recovery rate (RR) of IPB-D1 rooster's spermatozoa with different Immunoglobulin Yolk (IgY) concentrations. This study used 20 IPB-D1 rooster aged 8 month, consisting of 10 head with low IgY and 10 head with high IgY concentrations. The variables observed were the performance of IPB-D1 rooster feed consumption, weight gain, morbidity, and mortality, semen quality, and frozen semen quality. The results showed that there was no difference in the performance $(P>0.05)$ between IPB-D1 roosters with low IgY and high IgY concentrations. Semen consistency of rooster with low IgY was better than high IgY concentration. Sperm motility and viability of IPB-D1 rooster with high IgY concentration were better than with low IgY concentration. Sperm concentration per $\mathrm{ml}$ and total number sperm per ejaculate of IPB-D1 rooster with high IgY concentrations were lower $(P<0.05)$ than those with high IgY concentrations. There was no difference in the mass movement and sperm abnormalities in the two groups of the rooster. The quality of IPB-D1 rooster frozen semen with high IgY concentration was better than with low IgY concentration, but there was no difference in recovery rates between the two groups. This study concluded that the difference of IgY concentration in IPB-D1 chickens did not affect chicken performance and recovery rate, but it did affect some of the semen quality variables.
\end{abstract}

Keywords: IPB-D1 chicken, sperm freezability, semen characteristics, performance 


\section{PENDAHULUAN}

Ayam IPB-D1 merupakan ayam komposit hasil persilangan antara jantan $F_{1}$ PS (Pelung $x$ Sentul) dengan betina $F_{1}$ (Kampung $\times$ Ras pedaging paren stock (obb) dengan komposisi genetik masingmasing $25 \%$. Persilangan dari beberapa ayam asli tersebut didasarkan pada keunggulan dari tetuanya. Ayam pelung memiliki bentuk tubuh yang besar sehingga berpotensi menghasilkan daging lebih banyak. Ayam sentul memiliki produksi telur tinggi, pada umur 10 minggu ayam sentul memiliki bobot badan sebesar 722.00-833.25 g (Suherman et al., 2020). Ayam kampung umur 12 minggu bobot badan sebesar $921.67 \pm 61.23 \mathrm{~g}$ ekor $^{-1}$ dan ayam broiler umur 5 minggu mempunyai bobot badan sebesar $1550.26 \pm 30.71 \mathrm{~g}$ ekor $^{-1}$ (Ulupi et al., 2016). Persilangan tersebut bertujuan untuk meningkatkan kecepatan pertumbuhan dibandingkan dengan tetuanya. Tujuan tersebut telah tercapai dengan peningkatan bobot badan ayam IPB-D1 sebesar $1514 \pm 57.42 \mathrm{~g}$ ekor $^{-1}$ pada umur 12 minggu (Ulupi et al., 2016).

Ketahanan erat kaitannya dengan sistem kekebalan tubuh yang ditunjang oleh fungsi sel imun serta produksi antibodi. Ketahanan tubuh atau sering disebut dengan sistem imun merupakan suatu respon tubuh untuk melawan bibit penyakit seperti bakteri, virus, jamur, dan parasit yang dapat menginfeksi tubuh (Abbas et al., 2015). Ketahanan tubuh dapat dipengaruhi oleh beberapa faktor seperti pakan, manajemen pemeliharaan dan genetik. Beberapa jenis unggas menurut Hau \& Hendriksen (2005), khususnya pada ayam memiliki sensitivitas tinggi terhadap pemaparan antigen asing, sehingga sistem imun sangat responsif dan persisten untuk produksi Immunoglobulin Yolk (IgY)

Immunoglobulin yolk merupakan antibodi yang terdapat pada unggas, reptil, dan amfibi yang berfungsi menyediakan pertahanan untuk melawan agen infeksius, sama dengan fungsi IgG pada mamalia (Silveira et al., 2014). Immunoglobulin adalah senyawa protein yang disekresikan oleh limfosit B sebagai suatu respon terhadap paparan antigen dan efektor utama dari produk imunitas humoral. Sistem imun menurut Abbas et al. (2015) memiliki peranan penting untuk menghindari dan melawan berbagai jenis penyakit. Ketahan tubuh tinggi memiliki korelasi yang negatif terhadap performa produksi, namun terhadap kualitas semen masih belum diketahui.

Ayam jantan yang dapat digunakan sebagai pejantan sangat diperlukan kondisi performa reproduksi yang tinggi, performa reproduksi dipengaruhi oleh beberapa faktor seperti pakan, manajemen lingkungan, genetik, dan kualitas semen. Kualitas semen merupakan suatu aspek penilaian terhadap tingkat fertilitas spermatozoa. Kualitas semen dapat dinilai dengan melakukan pengamatan secara makroskopis dan mikroskopis. Pengamatan makroskopis meliputi volume, warna, konsistensi, dan pH, sedangkan mikroskopis yaitu gerakan massa, motilitas, viabilitas, konsentrasi, dan abnormalitas spermatozoa (Zelleke et al., 2005).

Penelitian mengenai kualitas semen ayam sudah banyak dilakukan tapi penelitian pada ayam IPB-D1 masih belum banyak. Hasil penelitian Ariyanti et al. (2018) menyatakan bahwa ayam sentul dengan IgY rendah menghasilkan volume semen dan konsentrasi spermatozoa yang rendah. Gambaran karakteristik semen ayam IPB-D1 secara umum telah dilaporkan Setiadi et al. (2019) namun berdasarkan konsentrasi IgY belum dilakukan.

Kriopreservasi semen merupakan salah satu metode bioteknologi reproduksi secara sederhana yang digunakan untuk mengawetkan plasma nutfah atau materi genetik. Tujuan kriopreservasi semen adalah memperpanjang daya hidup spermatozoa dengan dibekukan, sehingga dapat digunakan dalam jangka waktu lebih lama (Blesbois, 2007; Roushdy et al., 2014). Teknik kriopreservasi menjadi alat yang sangat berharga bagi industri unggas, oleh sebab itu untuk pelestarian sumber daya genetik unggas yang masih ada maka perlu dilakukan kriopreservasi semen.

Freezability merupakan daya tahan spermatozoa terhadap pembekuan, kualitas semen beku ayam sampai saat ini masih rendah, maka perlu dilakukan pengujian freezability dari semen ayam IPB-D1 yang memiliki konsentrasi IgY berbeda. Penelitian mengenai konsentrasi IgY terhadap kualitas semen ayam IPB-D1 belum pernah dilakukan, oleh karena itu penelitian ini bertujuan untuk mengevaluasi kualitas semen dan freezability spermatozoa ayam IPB-D1 dengan konsentrasi IgY berbeda, sehingga diharapkan ayam dengan konsentrasi IgY tinggi dapat menghasilkan semen yang berkualitas.

\section{BAHAN DAN METODE}

Bahan yang digunakan dalam penelitian ini adalah ayam IPB-D1 jantan sebanyak 20 ekor berumur 8 bulan dengan bobot badan rerata ayam penelitian 1.9 kg ekor ${ }^{-1}$, pakan komersial layer, desinfektan, vitamin tambahan, $\mathrm{NaCl}$ fisiologis, formolsalin, kertas tissue, alkohol 70\%, aquadest, eosin nigrosin, pengencer ringer laktat kuning telur, DMSO, dan $\mathrm{N}_{2}$ cair. 


\section{Pengujian Konsentrasi IgY Ayam IPB-D1 Jantan}

Pengujian konsentrasi IgY dilakukan pada 20 ekor ayam IPB-D1 jantan. Pengujian total IgY dalam serum darah dilakukan dengan menggunakan metode indirect Enzyme Linked Immunosorbent Assay (ELISA). Total IgY dari seluruh sampel direratakan. Total rerata IgY ayam IPB-D1 jantan adalah $9.36 \pm 2.88 \mathrm{mg}$ $\mathrm{mL}^{-1}$. Ayam yang memiliki konsentrasi IgY di atas rerata termasuk dalam kategori IgY tinggi dan ayam dengan konsentrasi IgY sama atau di bawah rerata termasuk dalam kategori lgY rendah.

\section{Pemeliharaan Ayam}

Ayam IPB-D1 jantan dipelihara pada umur 8 bulan sampai umur 10 bulan dan ditempatkan pada kandang individu (sangkar) sebanyak 20 petak yang terbuat dari bambu. Ukuran sangkar yaitu $50 \times 35 \times$ $60 \mathrm{~cm}$. Sangkar berada dalam bangunan kandang yang berukuran $5 \times 8 \mathrm{~m}$. Masing-masing sangkar lengkapi tempat makan dan minum. Kandang dilengkapi dengan lampu berdaya $20 \mathrm{~W}$ sebagai penerangan pada malam hari. Ayam diberi pakan komersial fase layer dengan kandungan protein 1618\%. Ayam selama penelitian ditimbang setiap minggu untuk mengetahui pertambahan bobot badan. Sisa pakan pada masing-masing ayam dihitung untuk mengetahui konsumsi pakan.

\section{Evaluasi Performa Ayam IPB-D1}

Evaluasi performa ayam IPB-D1 dengan konsentrasi IgY tinggi dan IgY rendah meliputi:

1. Konsumsi pakan (g ekor ${ }^{-1}$ ) didapatkan dari jumlah pemberian pakan dikurangi sisa pakan

2. Bobot badan akhir (g ekor $\left.{ }^{-1}\right)$ adalah bobot badan ayam pada akhir penelitian

3. Morbiditas (\%) didapatkan dengan menghitung jumlah ayam yang sakit dibagi jumlah total ayam dikali seratus persen

4. Mortalitas (\%) didapat dengan menghitung jumlah ayam yang mati dibagi jumlah total ayam dikali seratus persen.

\section{Pengujian Karakteristik Semen Ayam IPB-D1}

\section{b. Koleksi Semen}

Koleksi semen ayam dilakukan menggunakan teknik pengurutan (masase) dimulai dari bagian punggung ayam dan sampai $1 \mathrm{~cm}$ di belakang kloaka. Bagian kloaka sebelum koleksi dibersihkan dengan tissu yang diberi $\mathrm{NaCl}$ fisiologis. Koleksi semen dilakukan oleh dua orang, satu orang memegang ayam dan melakukan masase, satu orang lainnya bertindak sebagai kolektor semen. Koleksi semen segar dilakukan empat kali. Koleksi semen mengikuti metode Arifiantini (2012).

\section{a. Evaluasi Semen}

Semen dievaluasi secara makroskopis dan mikroskopis mengacu Arifiantini (2012) dengan beberapa modifikasi. Evaluasi secara makroskopis dilakukan terhadap volume, warna, konsistensi dan $\mathrm{pH}$. Volume semen dilihat dari spoit yang digunakan untuk koleksi semen, $\mathrm{pH}$ semen diukur dengan menggunakan $\mathrm{pH}$ special indicator paper (Merk skala 6.4-8). Pengamatan konsistensi semen dibedakan antara encer (1), sedang (2) dan kental (3). Warna dilihat secara visual dibedakan menjadi putih keruh (1), putih susu (2) dan krem (3). Evaluasi secara mikroskopis terdiri atas gerakan massa, motilitas, viabilitas, konsentrasi dan abnormalitas spermatozoa.

\section{Pengujian Freezability Ayam IPB-D1}

\section{a. Penyiapan Bahan Pengencer}

Bahan pengencer yang digunakan mengacu pada Junaedi et al. (2016), yaitu ringer laktat, kuning telur dan Dimethil sulfoksida (DMSO). Ringer laktat dan kuning telur (RLKT) dihomogenkan menggunakan stirer selama lima menit kemudian disentrifugasi selama 10 menit dengan kecepatan $3.000 \mathrm{rpm}$. Supernatan digunakan sebagai pengencer dasar dan diberi 7\% DMSO sebagai krioprotektan. Pengencer ditambahkan tris (Tris hydroxymethyl) aminomethane untuk mendapatkan pH 6.8.

\section{b. Koleksi dan Evaluasi Semen}

Koleksi dan evaluasi semen dilakukan seperti pada tahap pengamatan karakteristik semen. Semen dari dua kelompok konsentrasi lgY yang menunjukkan motilitas spermatozoa lebih dari $70 \%$ dengan konsentrasi spermatozoa lebih dari $2000 \times 10^{6}$ per $\mathrm{mL}$ masing-masing diencerkan dengan pengencer RLKT dan $7 \%$ DMSO. Dosis spermatozoa adalah $50 \times 10^{6} \mathrm{per}$ $0.25 \mathrm{~mL}$. Pengenceran semen dilakukan menggunakan formulasi umum: volume semen $(\mathrm{mL}) x$ motilitas spermatozoa (\%) $\mathrm{x}$ konsentrasi spermatozoa $\left(10^{6}\right.$ sel $\mathrm{mL}^{1}$ ) dibagi $50 \times 10^{6}$.

Semen yang telah diencerkan dikemas ke dalam mini straw $0.25 \mathrm{~mL}$ (Minitub, Germany) dan disusun dalam rak pembekuan. Straw berisi semen selanjutnya 
diekuilibrasi pada suhu $5{ }^{\circ} \mathrm{C}$ selama dua jam (Junaedi et al., 2016). Semen yang telah diekuilibrasi dibekukan dalam uap nitrogen cair selama 10 menit kemudian disimpan pada kontainer nitrogen cair ($196^{\circ} \mathrm{C}$ ) hingga pengujian berikutnya.

\section{c. Pengujian Kualitas Semen Beku}

Pengujian kualitas semen beku dilakukan 24 jam setelah penyimpanan. Semen beku di-thawing dalam air hangat $\left(37^{\circ} \mathrm{C}\right)$ selama 30 detik. Pengujian dilakukan terhadap motilitas spermatozoa. Keberhasilan pembekuan juga dinilai dengan Recovery rate (RR) yaitu persentase spermatozoa yang berhasil pulih dari proses pembekuan. Perhitungan RR spermatozoa yang digunakan Garner \& Hafez (2000) menggunakan rumus sebagai berikut:

$\mathrm{RR}=\frac{\text { Pesentase spermatozoa motil pasca thawing }}{\text { Persentase spermatozoa motil semen segar }} \times 100 \%$

\section{Analisis Data}

Data performa, kualitas semen segar dan kualitas semen beku ayam IPB-D1 dianalisis menggunakan uji-t mengikuti rumus Mattjik \& Sumertajaya (2013) menggunakan program SAS. Data total mortalitas dan morbiditas yang diperoleh dianalisis secara deskriptif.

\section{HASIL}

\section{Performa Ayam IPB-D1 Jantan}

Performa ayam IPB-D1 jantan dengan konsentrasi IgY berbeda tidak menunjukkan perbedaan $(P>0.05)$ terhadap konsumsi pakan dan bobot badan. Ayam IPB-D1 dengan konsentrasi IgY rendah mempunyai morbiditas 30\% (3 ekor dari 10 ekor), lebih tinggi dibandingkan dengan ayam yang mempunyai konsentrasi IgY tinggi yaitu hanya 10\% (1 ekor dari 10). Ayam dengan konsentrasi lgY rendah lebih rentan terhadap penyakit dibandingkan dengan ayam IgY tinggi. Hasil analisis performa ayam IPB-D1 jantan yang digunakan disajikan pada Tabel 1.

\section{Kualitas Semen Ayam IPB-D1}

Hasil pengamatan kualitas semen ayam IPB-D1 secara makroskopis tidak menunjukkan adanya perbedaan $(P>0.05)$ pada volume, warna, dan $\mathrm{pH}$ semen, namun konsistensi semen berbeda $(P<0.05)$. Kualitas semen ayam secara mikroskopis, menunjukkan tidak terdapat perbedaan nilai gerakan massa dan abnormalitas spermatozoa $(P>0.05)$ antar ayam yang memiliki konsentrasi IgY rendah maupun tinggi (Tabel 2).

\section{Freezability spermatozoa Ayam IPB-D1}

Freezability adalah kemampuan spermatozoa bertahan terhadap proses pembekuan. Freezability spermatozoa ayam IPB-D1 dengan konsentrasi IgY tinggi dan rendah tidak berbeda $(P>0.05)$. Freezability dilihat dari nilai recovery rate ( $R R)$, yaitu nilai relatif perbandingan antara motilitas spermatozoa semen beku dibandingkan dengan motilitas spermatozoa semen segarnya. Hasil pengukuran Freezability spermatozoa ayam IPB-D1 jantan dengan konsentrasi IgY berbeda disajikan pada Tabel 3.

\section{PEMBAHASAN}

Penelitian ini menunjukkan tidak terdapat berbedaan performa ayam dari dua kelompok IgY. Hal tersebut dapat diartikan bahwa ayam yang memiliki konsentrasi IgY tinggi atau IgY rendah sama baiknya. Ayam yang digunakan dalam penelitian

Tabel 1 Performa produksi ayam IPB-D1 jantan dengan konsentrasi IgY berbeda

\begin{tabular}{lcc}
\hline Peubah & IgY rendah & IgY tinggi \\
\hline Konsumsi pakan (g/ekor) & $4034.1 \pm 320.44$ & $4056.4 \pm 465.73$ \\
Bobot badan akhir (g/ekor) & $2175 \pm 244.06$ & $2062.5 \pm 163.08$ \\
Morbiditas (\%) & 30 & 10 \\
Mortalitas (\%) & 0 & 0 \\
\hline
\end{tabular}


Tabel 2 Karakteristik semen ayam IPB-D1 jantan dengan konsentrasi IgY berbeda

\begin{tabular}{|c|c|c|}
\hline \multirow{2}{*}{ Peubah } & \multicolumn{2}{|c|}{ Konsentrasi IgY } \\
\hline & Rendah & Tinggi \\
\hline \multicolumn{3}{|l|}{ Makroskopis } \\
\hline Volume semen $(\mathrm{mL})$ & $0.18 \pm 0.09$ & $0.13 \pm 0.07$ \\
\hline Warna semen & $1.75 \pm 0.25$ & $1.55 \pm 0.11$ \\
\hline pH semen & $6.71 \pm 0.26$ & $6.65 \pm 0.18$ \\
\hline Konsistensi semen & $2.33 \pm 0.65 a$ & $1.75 \pm 0.55 b$ \\
\hline \multicolumn{3}{|l|}{ Mikroskopis } \\
\hline Gerakan massa spermatozoa & $2.08 \pm 0.90$ & $2.10 \pm 0.72$ \\
\hline Motilitas spermatozoa (\%) & $65.00 \pm 8.26 b$ & $71.25 \pm 8.41 a$ \\
\hline Viabilitas spermatozoa (\%) & $74.88 \pm 17.27 b$ & $86.73 \pm 4.87 a$ \\
\hline Abnormalitas spermatozoa (\%) & $54.38 \pm 17.99$ & $39.62 \pm 24.14$ \\
\hline 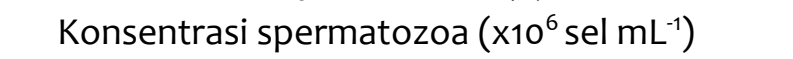 & $2258 \pm 974.78 a$ & $1234 \pm 711.75 b$ \\
\hline Konsentrasi spermatozoa ejakulat ${ }^{-1}\left(\times 10^{6}\right.$ sel) & $381.34 \pm 115.35 a$ & $174.46 \pm 75.53 b$ \\
\hline
\end{tabular}

Huruf yang berbeda pada baris yang sama menunjukkan perbedaan yang nyata $(\mathrm{P}<0.05)$.

Konsistensi 1 = encer, 2 sedang dan 3 kental; Warna 1 = putih keruh, 2 putih susu dan 3 krem

Tabel 3 Freezability spermatozoa ayam IPB-D1 jantan dengan konsentrasi IgY berbeda

\begin{tabular}{|c|c|c|}
\hline \multirow{2}{*}{ Peubah } & \multicolumn{2}{|c|}{ Konsentrasi IgY } \\
\hline & Rendah & Tinggi \\
\hline Motilitas spermatozoa Semen segar (\%) & $68.57 \pm 11.07$ & $77.86 \pm 3.93$ \\
\hline Motilitas spermatozoa Setelah thawing (\%) & $18.57 \pm 6.83 b$ & $27.14 \pm 5.99 a$ \\
\hline Recovery rate (RR) & $26.54 \pm 7.53$ & $34.97 \pm 7.92$ \\
\hline
\end{tabular}

Huruf yang berbeda pada baris yang sama menunjukkan perbedaan yang nyata $(\mathrm{P}<0.05)$

berumur 8-9 bulan, pada umur tersebut ayam telah memasuki masa produksi sehingga pakan yang dikonsumsi digunakan untuk mencukupi kebutuhan hidup dan berproduksi. Ayam dipelihara dalam kondisi lingkungan seragam dan pakan yang digunakan memiliki kandungan nutrisi sama. Konsumsi pakan dan bobot badan ayam oleh sebab itu tidak mengalami berbedaan. Hal ini sesuai dengan Astuti (2012) yang menyatakan bahwa konsumsi pakan dipengaruhi oleh kualitas pakan, palatabilitas dan umur ayam. Performa produksi merupakan salah satu indikator pertumbuhan yang dapat dicapai selama masa pemeliharaan.

Ayam-ayam dengan konsentrasi IgY rendah pada penelitian ini selama masa pemeliharaan terpapar agen penyakit yang menyebabkan coryza atau pilek. Penyakit coryza yang dialami memiliki gejala mengeluarkan cairan mata, pembengkakan sekitar area mata, sayap menggantung, bersin-bersin, nafsu makan menurun, hidung berlendir kental dan berbau.
Morbiditas pada ayam pedaging yang terserang penyakit tetelo (Newcastle Disease) $7 \%$ dan tingkat mortalitas 7\% (Risa et al., 2014). Ariyanti et al. (2018) melaporkan ayam sentul dengan IgY rendah lebih rentan terserang penyakit ngorok sebanyak 30\%. Hasil penelitian ini juga menunjukkan ayam-ayam IPB-D1 dengan konsentrasi IgY rendah lebih banyak terpapar penyakit, namun tidak menyebabkan kematian selama pemeliharaan.

Ayam dengan IgY rendah memiliki konsistensi semen yang lebih kental daripada IgY tinggi. Ayam dengan IgY rendah memiliki konsistensi semen yang sedang (skor 2.33 \pm 0.65 , skala 1-3), sedangkan ayam dengan IgY tinggi lebih encer (1.75 \pm 0.55$)$. Konsistensi ayam IPB-D1 dilaporkan memiliki konsistensi sedang hingga kental (Setiadi et al., 2019). Konsistensi dan warna semen dapat menggambarkan konsentrasi spermatozoa (Junaedi et al., 2016). Konsistensi semen berbeda-beda bergantung rumpun ayam. Ayam Bangkok memiliki konsistensi semen yang 
kental dengan konsentrasi spermatozoa $5754 \pm 3967$ $\mathrm{x} 10^{6}$ (Hijriyanto et al., 2017). Ayam kampung dengan konsistensi semen kental juga menunjukkan konsentrasi spermatozoa $3126 \pm 84.22 \times 10^{6}$ (Junaedi et al., 2016).

Spermatozoa aktif, pergerakan secara progresif serta banyak bergerak menandakan bahwa gerakan massa spermatozoa baik. Nilai gerakan massa termasuk sedang yaitu $2.08 \pm 0.90$ sampai $2.10 \pm 0.72$ dalam skala 1 sampai 3. Ayam IPB-D1 dengan konsentrasi IgY berbeda menunjukkan gerakan massa spermatozoa baik $(++/ 2)$. Hidayat et al. (2016) melaporkan bahwa gerakan massa spermatozoa ayam pelung $(+++)$. Gerakan massa spermatozoa Ayam IPB-D1 lebih rendah dibandingkan dengan ayam pelung, namun masih dalam kisaran normal.

Abnormalitas spermatozoa cukup tinggi pada kedua kelompok ayam dengan konsentrasi IgY rendah maupun tinggi. Abnormalitas spermatozoa ayam IPB-D1 dalam penelitian ini termasuk tinggi yaitu antara $39.62 \pm 24.14$ sampai dengan $54.38 \pm 17.99$ $\%$. Abnormalitas spermatozoa ayam IPB-D1 menurut Setiadi et al. (2019) adalah $14.79 \pm 4.67 \%$. Abnormalitas spermatozoa pada rumpun ayam lokal antara $6.79 \pm 1.20 \%$ sampai $6.82 \pm 1.50 \%$ pada ayam sentul (Ariyanti et al., 2018), pada ayam kampung 4.31 \pm 0.76 (Pratiwi et al., 2019) sampai dengan 7.33 $\pm 0.91 \%$ (Junaedi et al., 2016). Abnormalitas spermatozoa pada ayam SK kedu $2.99 \pm 4.55 \%$ (Hambu et al., 2016) sampai 3.00 $\pm 0.45 \%$ (Pratiwi et al., 2019) dan ayam merawang $2.58 \%$ sampai $3.23 \pm 0.70$. (Magfira et al., 2017; Pratiwi et al., 2019). Abnormalitas spermatozoa dapat memengaruhi tingkat fertilitas ( $A x$ et al., 2000). Hasil tersebut lebih rendah dibandingkan ayam IPB-D1 dengan IgY tinggi maupun rendah.

Ayam IPB-D1 dengan konsentrasi IgY tinggi menunjukkan motilitas spermatozoa lebih baik dibandingkan dengan yang memiliki IgY rendah $(P<0.05)$. Motilitas spermatozoa ayam IgY tinggi $71.25 \pm 8.41 \%$ sedangkan IgY rendah hanya $65.00 \pm 8.26 \%$. Motilitas merupakan daya gerak individu spermatozoa yang berperan penting dalam terjadinya fertilisasi (Danang et al., 2012). Motilitas spermatozoa pada ayam berkisar antara 60-80\% (Garner \& Hafez 2000). Motilitas spermatozoa ayam dengan IgY rendah meskipun lebih rendah, namun masih dalam kisaran motilitas spermatozoa yang normal. Setiadi et al. (2019) melaporkan motilitas spermatozoa pada ayam IPB-D1 $75.00 \pm 6.27 \%$ pada ayam sentul dengan IgY tinggi $72.00 \pm 2.00 \%$ dan IgY rendah $76.00 \pm 19.00 \%$ (Ariyanti et al., 2018).

Viabilitas spermatozoa ayam dengan IgY tinggi juga menunjukkan nilai yang lebih baik daripada ayam yang memiliki konsentrasi IgY rendah $(\mathrm{P}<0.05)$. Nilai viabilitas spermatozoa dengan konsentrasi IgY tinggi adalah $86.73 \pm 4.87 \%$ sedangkan yang mempunyai konsentrasi IgY rendah hanya $74.88 \pm 17.27 \%$. Viabilitas spermatozoa juga merupakan indikator penentu untuk mengetahui baik buruknya kualitas semen. Viabilitas semen ayam berbeda-beda bergantung rumpun ayam dan teknik pewarnaan yang digunakan. Nilai viabilitas spermatozoa ayam kampung $85.30 \pm 9.09 \%$ (Murcahyana et al., 2016), ayam sentul $90.64 \pm 1.21 \%$, ayam pelung $89.17 \pm 1.23 \%$ (Junaedi \& Husnaeni, 2019) dan ayam kedu $86.99 \pm 2.14 \%$ (Saleh et al., 2017).

Nilai viabilitas spermatozoa ayam dengan konsentrasi lgY rendah masih tergolong normal. Ariyanti et al. (2018) melaporkan bahwa viabilitas spermatozoa ayam sentul dengan IgY tinggi dan IgY rendah tidak berbeda dengan nilai $80.77 \pm 3.90 \%$ sampai dengan $83.09 \pm 2.60 \%$. Viabilitas ayam IPB-D1 dibandingkan dengan beberapa ayam lokal tersebut masih dalam kisaran baik. Hal ini diduga pada saat koleksi semen, ayam dalam kondisi sehat, sehingga pada kondisi tersebut organ reproduksi dapat berfungsi baik.

Konsentrasi spermatozoa adalah jumlah sel spermatozoa per ml. Konsentrasi spermatozoa ayam IPB-D1 dengan IgY tinggi hanya 1234.06 \pm 711.75 $\mathrm{x} 10^{6}$ lebih rendah dibandingkan dengan ayam dengan konsentrasi lgY rendah $2258 \pm 974.78 \times 10^{6}$. Konsentrasi spermatozoa ayam IPB-D1 telah dilaporkan sebelumnya oleh Setiadi et al. (2019), dengan nilai $3257.50 \pm 1303.14 \times 10^{6}$. Hasil penelitian ini berbeda dengan laporan Ariyanti et al., (2018), pada rumpun ayam sentul justru ayam-ayam dengan konsentrasi IgY tinggi memiliki konsentrasi spermatozoa lebih tinggi dibandingkan dengan konsentrasi IgY rendah.

Konsentrasi spermatozoa ayam sebetulnya lebih tinggi dibandingkan dengan ternak lain. Tingginya konsentrasi spermatozoa ayam akibat tidak terdapatnya plasma semen seperti yang dimiliki ternak lain, sebagai contoh pada ayam kampung bisa mencapai $3130 \pm 290.30 \times 10^{6}$ (Danang et al., 2012). Rendahnya konsentrasi spermatozoa dapat dipengaruhi oleh faktor individu ayam dan strain yang digunakan (Ajayi et al., 2011). Ayam IPB-D1 merupakan ayam silangan, kemungkinan hal tersebut penyebab rendahkan konsentrasi spermatozoa.

Konsentrasi spermatozoa ayam per $\mathrm{mL}$ berbeda dengan konsentrasi spermatozoa per ejakulat. Semen ayam mempunyai volume yang rendah. Volume semen ayam rata-rata $0.10 \mathrm{~mL}$ (Setiadi et al., 2019) sampai dengan $0.40 \pm 0.19 \mathrm{~mL}$ (Hambu et al., 2016). Volume semen ayam IPB-D1 pada penelitian ini adalah 
$0.13 \pm 0.07$ sampai dengan $0.18 \pm 0.09 \mathrm{~mL}$. Rendahnya volume semen menyebabkan konsentrasi spermatozoa perejakulat pada ayam menjadi rendah dibandingkan dengan konsentrasi spermatozoa per $\mathrm{mL}$. Konsentrasi spermatozoa perejakulat pada ayam-ayam IPB-D1 yang memiliki konsentrasi IgY yang rendah $\left(381.34 \pm 115.35 \times 10^{6}\right)$ juga ternyata lebih tinggi $(P<0.05)$ dibandingkan dengan ayam yang memiliki konsentrasi IgY tinggi $\left(174.46 \pm 75.53 \times 10^{6}\right)$.

Nilai RR dari ayam-ayam dengan konsentrasi IgY rendah dan tinggi tidak berbeda, dengan nilai antara $26.54 \pm 7.53$ sampai dengan $34.97 \pm 7.92 \%$. Nilai RR tersebut lebih rendah dibandingkan dengan nilai RR pada ayam kampung yaitu $44.45 \pm 1.78 \%$ (Junaedi et al., 2016) atau ayam SK kedu $49.35 \pm 2.03 \%$ (Telnoni et al., 2017). Nilai RR dipengaruhi oleh rumpun dan individu ternak. Motilitas spermatozoa semen segar ayam dalam penelitian ini tidak berbeda yaitu $68.57 \pm 11.07 \%$ IgY sampai dengan $77.86 \pm 3.93 \%$. Motilitas spermatozoa setelah thawing berbeda $(P<0.05)$. Motilitas spermatozoa setelah thawing pada ayamayam dengan konsentrasi IgY rendah hanya $18.57 \pm 6.83 \%$ sedangkan ayam-ayam dengan IgY tinggi adalah $27.14 \pm 5.99 \%$

Ayam IPB-D1 jantan yang memiliki konsentrasi IgY rendah dan IgY tinggi tidak berbeda (konsumsi pakan, bobot badan dan mortalitas). Motilitas dan viabilitas spermatozoa ayam dengan konsentrasi lgY tinggi lebih baik dibandingkan dengan konsentrasi IgY rendah. Konsentrasi spermatozoa per $\mathrm{mL}$ dan konsentrasi spermatozoa per ejakulat ayam dengan konsentrasi IgY rendah lebih baik daripada konsentrasi IgY tinggi. Freezability ayam-ayam dengan konsentrasi IgY rendah dan IgY tinggi tidak berbeda.

"Penulis menyatakan tidak ada konflik kepentingan dengan pihak-pihak yang terkait dalam penelitian ini".

\section{DAFTAR PUSTAKA}

Abbas AK, Lichtman AH, Pillai S. 2015. Celluler and Molecular Immunology. $6^{\text {th }}$ Ed. Saunders. Elsevier. Ajayi FO, Agaviezor BO, Ajuogu PK. 2011. Semen characteristics of three strains of local coocks in the humid tropical environtment of Nigeria. International Journal of Animal and Advences 3(3): 125-127.

Arifiantini RI. 2012. Teknik Koleksi dan Evaluasi Semen pada Hewan. Institut Pertanian Bogor Press. Bogor.
Ariyanti R, Ulupi N, Suryati T, Arifiantini RI. 2018. Performa produksi dan reproduksi ayam sentul dengan konsentrasi igy berbeda dalam serum darah. Jurnal Ilmu Produksi dan Teknologi Hasil Peternakan 5(3): 89-93.

Astuti N. 2012. Kinerja ayam kampung dengan ransum berbasis konsentrat briler. Jurnal Agrisains 4(5): 51-58.

Ax RL, Dally MR, Didion BA, Lenz RW, Love CC, Varner DD, Hafez B, Bellin ME. 2000. Semen Evaluation. In. Hafez B, Hafez ESE (eds.). Reproduction in Farm Animals. 7th ed. Lippincot Williams and Wilkins. South Carolina.

Blesbois E. 2007. Current status in avian semen cryopreservation. World's Poultry Science Journal 63(2): 213-222.

Danang DR, Isnaini N, Trisunuwati P. 2012. Pengaruh lama simpan semen terhadap kualitas spermatozoa ayam kampung dalam pengencer ringer's pada suhu $40^{\circ} \mathrm{C}$. Jurnal Ternak Tropika 13(1): 47-57.

Garner DL, Hafez ESE. 2000. Spermatozoa and Seminal Plasma. In: Hafez B, Hafez ESE (eds). Reproduction In Farm Animals. 7th ed. Lippincott Williams and Wilkins. South Carolina.

Hambu EK, Arifiantini RI, Purwantara B, Darwati S. 2016. Raw semen characteristics of three different indonesian local roosters. Animal Production 18(3): 165-172.

Hau J, Hendriksen CFM. 2005. Refinement of polyclonal antibody production by combining oral immunization of chickens with harvest of antibodies from the egg yolk. ILAR Journal 46(3): 294-299.

Hidayat N, Sumantri C, Afnan R, Arifiantini RI. 2016. Penentuan konsentrasi sodium dodecyl sulfate dalam pengencer ringer laktat-kuning telur untuk preservasi semen Ayam Pelung. Jurnal Kedokteran Hewan 10(2): 170-174.

Hijriyanto M, Dasrul, Thasmi CN. 2017. Pengaruh frekuensi penampungan semen terhadap kualitas spermatozoa pada Ayam Bangkok. Jurnal Ilmiah Mahasiswa Veteriner. 1(1): 46-53.

Junaedi, Arifiantini RI, Sumantri C, Gunawan A. 2016. Penggunaan dimethyl sulfoxide sebagai krioprotektan dalam pembekuan semen Ayam Kampung. Jurnal Veteriner 17(2): 300-308.

Junaedi, Husnaeni. 2019. Kaji banding kualitas semen segar empat genetik ayam lokal indonesia. Jurnal Veteriner 20(3): 397-402.

Magfira, Arifiantini RI, Karja NWK, Darwati S. 2017. Efektivitas low density lipoprotein dan kuning telur 
ayam dan puyuh pada pengawetan semen Ayam Merawang. Jurnal Veteriner 18(3): 345-352.

Mattjik AA, Sumertajaya M. 2013. Perancangan Percobaan dengan Aplikasi SAS dan Minitab Jilid I. IPB Press. Bogor.

Murcahyana, Susilawati T, Isnaini N. 2016. Pengaruh pemberian ekstrak buah mengkudu (Morinda

citrifolia) dalam larutan natrium klorida fisiologis sebagai bahan pengencer semen terhadap peningkatan kualitas spermatozoa Ayam Buras pada suhu ruang. Jurnal Kedokteran Hewan 10(2): 175-180.

Pratiwi N, Yusuf TI, Arifiantini RI, Sumantri C. 2019. Kualitas spermatozoa dalam modifikasi pengencer ringer laktat kuning telur dengan tambahan astaxanthin dan glutathione pada tiga jenis ayam lokal. Acta Veterinaria Indonesiana 7(1): 46-54.

Risa E, Samaun R, Novita ID. 2014. Evaluasi penurunan angka mortalitas dan morbiditas ayam pedaging yang mendapatkan penambahan tepung lempuyang (Zingiber aromaticum val) dalam ransum. Jurnal Galung Tropika 3(3): 192-200.

Roushdy Kh, El-Sherbieny MA, Abd El-Gany FA, ELSayed MA. 2014. Semen cryopreservation for two local chicken strains as A tool for conservation of Egyptian local genetic resources. Egyptian Poultry Science Journal 34(2): 607-618.

Saleh DM, Mugiyono S, Mufti M. 2017. Pengaruh frekuensi penyadapan semen terhadap kualitas spermatozoa pada Ayam Sentul. Journal Lembaga Penelitian Pengabdian Masyarakat 7(1): 9-17.
Setiadi DR, Hasibuan H, Indriastuti R, Arif AA, Rosyada ZNA, Arifiantini RI, Sumantri C. 2019. Karakteristik semen ayam IPB-D1. Jurnal Ilmu Produksi dan Teknologi Hasil Peternakan. 7(2): 57-61.

Silveira L, Vargas GD, Fischer G, Lima M, Esteves PA, Hubner SO. 2014. Avian IgY antibodies: characteristics and applications in immunodiagnostic. Ciencia Rural 44(1): 153-160.

Suherman A, Mahmud Y, Ambasari W, Hernaman I, Yuhani H, Salim R. 2020. Performa Ayam Sentul yang diberi ransum mengandung Indigofera zollingeriana. Jurnal Ilmu dan Teknologi Peternakan Tropis 7(1): 8-14.

Telnoni SP, Arifiantini RI, Yusuf TL, Darwati S. 2017. SK kedu semen cryopreservation in beltsville poultry semen extender and lactated ringer'segg yolk extender using dimethyl sulfoxide. Asian Jurnal of Poultry Science 11(1): 14-19.

Ulupi N, Sumantri C, Darwati S. 2016. Resistance against Salmonella pullorumin IPB-D1 crossbreed, kampong and commercial broiler chicken. The 1st Conference Technology on Biosciences and Social Sciences 2016. Univeritas Andalas. Padang.

Zelleke G, Moudgal RP, Asmera A. 2005. Fertility and hatchability in RIR and WL as functionally modified by crossing them in alternate sex combinations (Gallus domestics). Journal British Poultry Science 46: 119-123. 